\title{
"FOR HEART, PATRIOTISM, AND NATIONAL DIGNITY": THE ITALIAN LANGUAGE PRESS IN NEW YORK CITY AND CONSTRUCTIONS OF AFRICA, RACE, AND CIVILIZATION
}

\author{
Peter G. Vellon \\ Queens College, The City University of New York
}

A day after the brutal lynching of eleven Italian immigrants in New Orleans in 1891, Il Progresso Italo-Americano published a front-page letter to the editor signed only by the name Marchese. A resident of Massachusetts, Marchese expressed outrage over the cruel work of the mob in New Orleans and added that his hometown of Springfield commiserated with the victims. Moreover, he expressed particular shock over how this could happen in a "civilized" nation such as America. Echoing a sentiment that prevailed throughout the Italian American press, Marchese concluded that the barbaric act of lynching might be expected in Africa tenebrosa (dark, murky), but not in the United States. ${ }^{1}$ In a letter to Cristofero Colombo, another New York Italian American daily, reader Alberto Dini went one step further by maintaining that "not even the savage population of Central Africa would approve of such a disgraceful action." 2 For the Italian language mainstream press in general, the line between African savagery and American civilization had become blurred: "But where are we? The only difference now between the free sons of America and the savages of Africa is that Americans have yet to become flesh eating cannibals." 3 In a scathing indictment of American lawlessness, African savagery was held as the standard against which to judge American society. In response to Dini's letter, the Cristofero Colombo asserted "at least cannibals respect the laws of primitive tribal justice so that a massacre like this would have been avoided." 4

1 Il Progresso Italo-Americano, March 16,1891; After the lynching of 3 Italians in Hahnville, Louisiana in 1893 a letter written to Il Progresso from a man in New York City echoed almost verbatim the sentiments of Marchese's letter. Again, the word tenebroso was used to describe the African continent. Ibid., July 30,1893.

2 Cristofero Colombo, March 18,1891. An article in Cristofero Colombo expressed outrage and surprise that such an atrocity "would happen in a 'civilized' nation such as America ... . if it had occurred in Africa this type of savagery would be more understandable." Ibid., March 20,1891.

3 L'Araldo Italiano, August 11,1896.

4 Cristofero Colombo, March 15,1891. 
Influenced by contemporary attitudes in Italy that exalted italianita by degrading the darker other, including southern Italians, Italian language newspapers in New York City remained quite comfortable with a racial hierarchy that positioned Africa as the lowest rung on the racial ladder. The image of Africa became a convenient trope for Italian language newspapers wrestling with their own questions of Italian American identity in a new and often inhospitable country that frequently doubted Italian racial fitness. Examining the African American press, Eric Vogel stressed that "a periodical analyzed as a cultural production creates an ideal stage for examining society. . .In this way, the press gives us the chance to see writers forming and reforming ideologies, creating and recreating a public sphere, and staging and restaging race itself." 5 During mass immigration, Italian language newspapers emerged out of necessity to fill a crucial void in the lives of an ever-increasing stream of settlers. Whether reporting on events in Italy, organizing subscription drives for Italian earthquake victims or memorials to Italian heroes, publishing employment advertisements, or information about labor organization, the Italian language press catered to its consumers and offered a life vest for many Italians grasping for normalcy in their new environment. Italian language newspapers played a pivotal role in this process by forging an Italian racial identity centered upon the exalted civilization of an Italian national past wiped clean of sectional discord and questionable racial character. ${ }^{6}$

For Italian immigrants negotiating a harsh, nativist environment, the pages of mainstream newspapers in New York City became a site for identity formation as editors and journalists put forth a fledgling notion of Italian identity that had only recently emerged out of post-unification Italy. Reacting to American violence against Italians, especially instances of lynching, Italian language newspapers propped up Italian civilization in stark contrast to the savage barbarism of American mob violence. Frequently New York's Italian language press constructed Africa as a primitive, savage continent, the polar opposite of European,

5 See Todd Vogel, Ed., The Black Press: New Literary and Historical Essays, (Rutgers University Press, NJ: 2001), 2-3.

6 For more on the role of the Italian immigrant press, and the immigrant press in general, see: Robert E. Park, The Immigrant Press and Its Control (Harper and Brothers Publishers, New York: 1922); Humbert Nelli, "The Role of the Colonial Press in the Italian American Community of Chicago, 1886-1921" ( Ph.D. diss., University of Chicago: 1965), 48. See also Rudolph Vecoli, "The Italian Immigrant Press and the Construction of Social Reality,18501920" in Print Cuiture in a Diverse America, James P. Danky and Wayne A. Wiegand, Eds.,(University of Illinois Press, Urbana: 1998); Christiane Harzig and Dirk Hoerder, Eds., The Press of Labor Migrants in Europe and North America, 1880s - 1930s (Publications of the Labor Newspaper Preservation project, University of Bremen: 1985); Sally Miller, Ed., The Ethnic Press in the United States: A Historical Analysis and Handbook, (Greenwood Press, CT: 1987). 
western societies and of ten employed the phrase continente Nero (black continent) or Africa tenebrosa (murky, dark Africa). ${ }^{7}$ Even radical Italian language newspapers appropriated this imagery, most forcefully to criticize those southern Italian immigrants whom they viewed as gullible and ignorant fools swindled by Catholic clergymen.

For mainstream newspapers, however, their portrayals of Africa as the savage, black continent, served multiple goals. Although utilizing such harsh rhetoric served to inflate their own sense of civilization and emerging Italian identity, Italy's colonial ventures in northern Africa in the 1890s and again in 1911-1912 would have a crucial impact on expediting the process. And, after suffering a bitter defeat to Ethiopia at Adowa in 1896, Italian success in Libya became even more important to sustaining an emerging Italian racial pride. Writing in 1922, Sociologist Robert Park maintained that mainstream newspapers such as Il Progresso served to break down the "local and provincial loyalties with which immigrants arrived, and a substituted a less intense but more national loyalty in its place." Implicit in this process, Park stressed, was the importance of the press in fostering, or creating, a hybrid identity, "neither American nor foreign, but a combination of both." 8 It would be this rhetoric of Italian civilization, often constructed in opposition to African savagery and championed by prominenti-owned newspapers that would inform how the Italian language press in New York City socially constructed categories of race, color, civilization, and identity.

$* * * * *$

In the late 19th and early 20th century American civilization became a topic of intense debate in the Italian language press as Italian immigrants faced negative perceptions, discrimination, and violence upon their arrival. Much like American contemporaries, Italian language newspapers subscribed to a hierarchical notion of race and designations of civilized and savage nations littered the pages of mainstream and radical newspapers. However, during this period Italian language newspapers consistently employed the image of Africa as the most appropriate way to convey savagery. For the Italian language mainstream press, in particular, dark Africa, or Africa tenebrosa, became a useful vehicle, a familiar language, to channel disappointment and outrage over American mistreatment and negative portrayals. "How can they be the most civilized people in the world if they lynch people," asked Il Progresso, "lynching only occurs in uncivilized nations .... And if it is a civilized nation, she [America] has a duty to educate the barbarians from the

7 L'Eco d'Italia, March 5,1896; L'Araldo Italiano, March 10,1896; Il Progresso ItaloAmericano, March 16,1891.

8 Quoted from Park, 79;84;87. 
South."9 Unlike their own claims supporting Italian colonial ventures into Africa, mainstream newspapers attacked American imperial claims of bearing the white man's burden. Indeed, the press ironically mocked American missionary excursions into China and central Africa in light of the uncivilized behavior directed at Italian immigrants in the United States. ${ }^{10}$ Perhaps the harshest contemporary criticism "demoted" American civilization to a racial classification akin to African. In 1899, mainstream Il Progresso declared "why do they say they[Americans] have to send people to civilize the barbarians in the Philippines when we have white Matabeli here in the United States." The word Matabeli is derived from the root word Matabeleland which is contemporary Zimbabwe. In this example, the uncivilized actions of Americans contradict their supposed mission to civilize Philipinos. However, by juxtaposing racial signifiers and giving the "savage" a white face, use of the term "white Matabeli" raised questions as to whether Il Progresso believed Americans could ever be completely equivalent to "uncivilized" and "black" Africans. ${ }^{11}$

In addition to New York's mainstream press, Italian language radical newspapers also embraced the familiar language of racial hierarchy, in particular the image of Africa tenebrosa. Whether inveighing against capitalism, southern Italian ignorance, religion, or prominenti, the radical press, much like its mainstream counterpart, often expressed its scorn and disappointment through comparisons to savage Africa. For example, in the anarchist La Questione Sociale an article entitled Ancient and Modern Cannibalism lamented the exploitive character of capitalism by juxtaposing modern nations with primitive societies. "We are worse than the savages because we have a keenly developed intellect and should know better .... in the so called civilized countries and especially in those we inhabit the form of savage African cannibalism does not exist .... however, many people are still killed by the thousands in different ways every day. ${ }^{12}$ Radical papers often employed the image of African savagery even when condemning race based theories of oppression. In 1916 the socialist Il Proletario sarcastically chided a Boston clergyman for promoting race purification theories. The paper added that the Reverend was fortunate his comments had a forum such as America "which is the land of the cowboys and where civilization is on par with the barbarians of equatorial Africa." Ironically, this example illuminates the facile manner in which the press could criticize racial hierarchy by simultaneously sustaining the image of primitive Africa to convey America's de-

\footnotetext{
9 Il Progresso Italo-Americano, July 29,1899.

10 Ibid., March 16,1891.

11 Ibid., August 5,1899.

12 La Questione Sociale, October 27,1906.
} 
scent into savagery. ${ }^{13}$ Similarly, many other examples utilized language likening American capitalism to "savage beasts from central Africa" 14 or "conquistadors of savage Africa."15

Perhaps the radical press' most compelling narrative compared southern Italians to African savages. Framed within the context of the sovversivi's virulent anticlericalism, immigrant religious traditions and rituals, such as public processions venerating local patron saints or madonnas, usually bore the brunt of sovversivi scorn. Italian immigrant feasts were described as festivals of "superstition, prejudice, and ignorance-a celebration of darkness in the middle of so much light, civility and progress." 16 Further, southern Italian immigrants were portrayed as "savage people from the backcountry of Calabria and Sicily-without shoes, with long hair resembling witches more than human beings. . . . "17 The radical press' critique illuminates how easily the civilization of southern Italians could be questioned and marginalized. In addition to condemning priests and prominenti, sovversivi took aim at mainstream Italian language newspapers such as Il Progresso Italo-Americano and Bolletino della Sera, criticizing them for their support of a "feast organized by a mass of criminals." 18 For example, ridiculing Italian immigrants and the mainstream newspaper Il Bolletino della Sera, the anarchist La Questione Sociale stated that "Italians above all people believe in miracles as if they were in the Middle Ages. . . . it is a conflict between ancient barbary and modern civilization." 19 From their perspective, some of the blame could be attributed to an infantile trust in priests that permeated southern Italian actions. The anarchist La Questione

13 In addition to outright comparisons associating savage Af ricans with southern Italians, for example, there was also the tendency to use Africans metaphorically in order to illuminate a point. For instance, in an article criticizing the prominenti-owned Italian language press in New York, Il Proletario maintained that these newspapers were vehicles for exploitation and prostitution and exclaimed in disgust that prominenti newpapers were full of such grotesque nonsense that "not even a Zulu would accept it." Il Proletario, October 28,1916.

14 La Questione Sociale, November 26,1904. After the fatal shooting of Giovanni Bazzani, a young Italian boy who mistakenly trespassed onto a farm in Clinton, Indiana, La Questione Sociale used this "unpardonable crime" to outline the evils of private property in the United States. In its outrage, La Questione Sociale complained, "Is this how American farmers defend their property? These crimes are so atrocious that they would horrify and disgust even savage beasts from central Africa."

15 See Il Proletario, June 2,1911. Il Proletario commonly referenced Africa as savage. For example, in one article critical of police on horseback, the newspaper stated that officers resembled the "conquistadors of savage Africa." Il Proletario, March 1,1912.

16 Ibid., July 19, 1902.

17 Ibid., July 21,1900. Mainstream newspapers used similar images of "barefoot" natives to convey the primitiveness of Africans. See L'Eco d'Italia, March 26, 1896; L'Araldo Italiano, March 20, 1896.

18 Il Proletario, July $21,1900$.

19 See La Questione Sociale, July 25,1903; See also similar comments regarding the medieval aspects of the Feast of La Madonna del Carmine from Paterson, New Jersey-a vibrant anarchist Italian colony. La Questione Sociale, July 27,1907. 
Sociale explained that this behavior was not unique to Italians, but had also been exhibited by the Zulu tribes of Africa. ${ }^{20}$

Much like its opponents in the mainstream Italian language press, the socialist Il Proletario remained quite conscious of the perception and image of Italian immigrants. To radicals, "ignorant, illiterate, superstitious southern Italian immigrants" had become an easy target for swindling priests and the prominenti who supported them. And, according to the Italian language radical press, spectacles such as religious feasts and processions were a clandestine ruse designed to divest the Italian working class of its wages. Every summer the religious feast held at Our Lady of Mt. Carmel in East Harlem elicited attention from socialist and anarchist newspapers and served to re-enforce existing images of civilization and savagery. Embarrassed and frustrated over the behavior of their countrymen and women, Italian radical newspapers excoriated southern Italian immigrants for their gullibility and ignorance. Il Proletario asked incredulously if the "orgies and fantasies of the pelli rosse (redskins) or the ottentoti (Hottentots) could be any more inferior to the sad spectacle our Italian colony has offered us the last few days?"21

\section{"THE HEARTS OF IMMIGRANTS BEAT IN UNISON WITH THAT OF MOTHER ITALY"}

Although the emergence in specific and meaningful ways of an Italian identity within the pages of Italian language mainstream newspapers was predicated upon constructing a civilized Italy, it also owed much to the persistent image of a black, African other. Since the Italian language press so frequently associated what was considered uncivilized or savage with Zulus and Hottentots, it was unsurprising that Italians perceived themselves as quite the opposite. And, for immigrant arrivals who did not possess a strong sense of nation, or Italian-ness upon arrival, the Italian government's late nineteenth and early twentieth century colonial wars with African countries served as a graphic example of this perceived racial hierarchy.

20 Ibid., September 30, 1905.

21 Il Proletario, July 21, 1900. Pelle rosse (redskin) was a frequently used term for Native Americans in both the mainstream and socialist press. Ottentoti derived from the Italian word ottentotto, meaning Hottentot, and referred to the language of the Khoiskhoin peoples of South Western Africa and Namibia. It was an oft used marker to distinguish savage from civilized in the Italian language press during the period of mass immigration. In 1915, Il Proletario used the same comparison to condemn Americans for their violent behavior towards African Americans. "This attack was in defense of property ownership and the victims were Black, however, the 'civil' people of society will say it was perpetrated 'without racism, without prejudice and was inspired by the highest sense of humanitarianism. If this is civility I would prefer to associate myself with the Hottentots of the Congo." See Il Proletario, September 4,1915 . 
Coming out of Italian unification in 1860, Italians wrestled with the task of constructing a unique Italian identity from the fractious provincial and regional identities that had dominated its history. Compared to European neighbors, Italy suffered from high illiteracy rates, low educational achievement, infrastructure problems, and low political participation that rendered the task of nation building rather bleak. However, using the state and the military as the means through which to consolidate power, Italy's bourgeoisie-held together by a common language and literature-used the language of patriotism to mold a nationalistic history connecting post-unification Italy to a distant past. According to John Dickie, the proliferation of racial stereotypes related to the problem of the mezzogiorno (Italian South) must be viewed within the context of upper class and elite Italian anxiety over the probability of creating a successful nation state after unification. ${ }^{22}$ Indeed, a critical theme informing nationalistic and patriotic attitudes disseminating within Italy's elite classes revolved around the emerging concept of the south as a region marked by backwardness and criminality, savagery and darkness. Fused with these perceptions was the mezzogiorno's negative connection to Africa, especially central Africa, as the ultimate image of darkness and savagery. One of the many factors creating "imagined communities," to borrow Benedict Anderson's phrase, is positing a normative value to one's version of nation by employing definitions of what it is not. During the late 19th and early twentieth century imagined constructions of Italian identity and Italian nationhood emerged simultaneously with alternate constructions of a backward, criminal, and African South. ${ }^{23}$

Following the example of other European states in the late nineteenth-century, Italy embarked on a colonial path into Africa. This was fueled by a belief that not only could European civilization deliver Africa from savagery, but African conquest would solve domestic problems as well. For the recently unified Italian nation, the "scramble for Africa" served to awaken political and popular consciousness about people of color and highlighted issues of national prestige, foreign diplomacy, and

22 See John Dickie, Darkest Italy: The Nation and Stereotypes of the Mezzogiorno, 18601900 (St. Martin's Press, NY: 1999), 1-23. See also Gabriella Gribaudi, "Images of the South: The Mezzogiorno as seen by Insiders and Outsiders," in Robert Lumley \& Jonathan Morris, Eds., The New History of the Italian South: The Mezzogiorno Revisited (University of Exeter Press, London: 1997); Vito Teti, Ed., La razza maladetta: origini del pregiudizio antimeriodionali (Manifestolibri, Rome: 1993); Claudia Petraccone, Le due civilta' (Laterza, RomeBari: 2000).

23 See Dickie, 18; Benedict Anderson, Imagined Communities: Reflection on the Origin and Spread of Nationalism (Verso, NY: 1983). 
domestic overpopulation. ${ }^{24}$ Quarrels with France over colonial possessions, trade agreements, and control of the Western Mediterranean caused Italy to come to the imperial table later than France and England. The French occupation of Tunis in 1881, in particular, was a heavy blow to Italy, both in prestige and national interests, especially since more than 9000 Italians settlers lived there as compared to only 200 French. In an attempt to protect her interests and prevent isolation in world power politics, Italy signed a defensive alliance with Germany and AustriaHungary known as the Triple Alliance. Although the alliance provided some sense of security, it did not give Italians the sense of pride and glory that many hungered for.

In its effort to carve a niche for itself on the African continent, Italy's initial interest centered on the Red Sea around the port of Massawa which she occupied in 1885. By 1890, Italy had established a protectorate over Ethiopia (Abyssinia) and pushed further inland linking their Red Sea possessions of Massawa and Assab to form Eritrea; Italy also began the conquest of Somalia, which formally became an Italian colony in 1905. According to Martin Clark, "Italian colonialism was not founded on any need to secure raw material supplies .... it was the agricultural crisis of the mid-1880s and the need to export social problems that underlay it, together with a frustrated desire for self-assertion." 25 Indeed, some of the greatest enthusiasm was to be found in the South, where the pervasiveness of agrarian misery and overpopulation made the idea of emigration to foreign territories under the Italian flag attractive. ${ }^{26}$ However, disputes between Empereor Menelik and the Italian government over Italian claims of a protectorate over Ethiopia, as well as campaigns to prevent the French from gaining a foothold in the region, resulted in the eruption of hostilities between Italian forces and Menelik's indigenous army. By the late 1890s Italy had become embroiled in a very expensive colonial war in Africa. ${ }^{27}$

Having had already experienced a bitter colonial defeat at Dogali in 1887, the battle of Adowa in March 1896 proved to be the most humiliating and enduring for the Italian military. Despite retaining the territories of Eritrea and Somalia, Adowa was a crushing blow for a nation attempting to claim colonial glory and honor by colonizing Africans. Massproduced pamphlets containing songs and poems were sold and circu-

24 For a more thorough discussion of the European quest for colonies in Africa in the late nineteenth century see Thomas Pakenham, The Scramble for Africa: White Man's Conquest of the Dark Continent From 1876 to 1912 (Avon Books, New York: 1991).

25 Martin Clark, Modern Italy 1871-1982 (Longman, New York: 1984), 47.

26 Christopher Seton-Watson, Italy from Liberalism to Fascism,1870-1925 (Methuen \& Co. Ltd., London: 1967), 118.

27 For a fuller discussion of Italian colonialism into Africa in the late nineteenth century, see Clark, 46-48; 99-101; Seton-Watson, 98-182. 
lated widely throughout the country in the aftermath of Adowa as the bitter defeat remained imbedded in the collective consciousness of Italians. One particular pamphlet Vittoria Italiana in Africa (Italian Victory in Africa) focused upon the period before Adowa as if to deny the defeat ever occurred. Instead, the epic poem described the honor and valor of Italian soldiers as they battled the "wicked and nasty" African soldiers. The image conveyed was that of the savage African who engages in military subterfuge that other civilized nations, such as Italy, would not employ in battle. Produced for mass propaganda, these kinds of pamphlets created a negative image of the African that seeped into the popular mind. ${ }^{28}$

Despite the disappointing outcome for many Italian immigrants, Italy's attempts to colonize Ethiopia in the 1890s functioned as an important element in community-formation within immigrant enclaves. ${ }^{29}$ For instance, during the Ethiopian campaign Italian immigrant organizations, such as Il Comitato Italiano in Baltimore, Maryland, dispersed leaflets to areas as far West as Denver, Colorado, to champion the cause of the homeland. Addressed to connazionali (countrymen), the leaflet stated that "although there is support in Italy, we here in the United States want to assert our solidarity with our brothers across the great ocean . . . our sentiments are so strong we need to assert ourselves as Italians." 30 Throughout the campaign, which had begun in January 1896, such manifestations of support for Italian victory over African forces appeared to be ubiquitous within the Italian immigrant communities from Lawrence, Massachusetts to Chicago, Illinois. ${ }^{31}$ Italian immigrants inaugurated new ethnic organizations that began by "saluting the heroic Italian soldiers in Africa and the hope for a deserved victory." 32 A group of Italian women in Chicago organized within the ethnic community a collection drive spe-

28 Pamphlet, "Storia della Vittoria Italiana in Africa e disfatta di Ras Mangascia," (Tipografia Adriano Salani, Viale Militare, Firenze: 1910). The illustration depicted an African man dressed in tunic, with braided hair held in place by metal rods, and protruding teeth.

29 According to Stefano Luconi, "stimulating a sense of nationalistic identity out of a military defeat. . .was rather difficult." However, despite the "shame" of losing to Menelik's indigenous forces, the emergence of a nascent national identity cannot be underestimated, nor dismissed, solely predicated upon the eventual negative outcome (from the Italian perspective). Indeed, the prevalence of rhetoric seeking to avenge the loss at Adowa during the Libyan campaign was proof of the effects that campaign had on identity formation in Italian immigrant communities. See Stefano Luconi, "The Impact of Italy's Twentieth-Century Wars on Italian Americans' Ethnic Identity" Nationalism and Ethnic Politics 13: 465-491, 2007.

30 Leaflet, Connazionali, January 21,1896, ASMAE, Ambasciata di Washington, busta 107, fascicolo 14, "Mobilitazione di italiani negli S.U. per la campagna d'Africa, 1896."

31 Francesco Marrocco to Consul General, New York, April 17,1896, Carlo Ginocchio to Italian Ambassador in Washington, D.C., April 2,1896, ASMAE, Ambasciata di Washington, busta 107, fascicolo 14, "Mobilitazione di italiani negli S.U. per la campagna d'Africa,1896."

32 Consul General of New York, April 17,1896, G.B.Rosasco to Italian Ambassador in Washington D.C., ASMAE, Ambasciata di Washington, busta 107, fascicolo 14, "Mobilitazione di italiani negli S.U. per la campagna d'Africa,1896.“ 
cifically for the war with Ethiopia, the proceeds of which were sent directly to Italy's Queen Margherita. ${ }^{33}$ Italian American men were sufficiently inspired to offer their lives in the war against Africa. In Colorado some wrote letters to the Italian Ambassador in Washington requesting permission to send volunteer soldiers to fight in Eritrea. ${ }^{34}$ In New York, one Italian captain was recruiting men to fight in the name of the Italian Ambassador until it was discovered that he was not authorized to do so. ${ }^{35}$ Perhaps the most symbolic example of the nationalist sentiment provoked by the African campaign is the letter sent by V.A. Scaletta in 1896. Having served in the Italian Cavalry in 1867, Scaletta asked the Italian Ambassador in Washington if he could be accorded the honor of serving as a simple soldier in the Italian war effort in Africa. ${ }^{36}$ Although the Italian Embassy politely refused all considerations for Italian American volunteer soldiers, not to mention a retired officer, such overtures illustrated the range of enthusiasm for Italian colonial aims in Africa.

Through all of this, however, the Italian language mainstream press remained instrumental in fomenting fierce national support and making the African campaign a cause celebre within Italian American communities. Newspaper owners such as Carlo Barsotti fostered a collective sense of Italian patriotism and fidelity to la patria most immigrants had never experienced. ${ }^{37}$ Mainstream newspapers in New York City justified Italian aggression in Africa on the basis of Italian civilization and coverage of the war frequently defended Italian colonial initiatives for that reason. According to L'Eco d'Italia, "success in civilizing the African and suppressing the inferior race will hopefully benefit the civilized world ... . Black, obscure Africa is almost coming into the light. European civilization will be imported by love or by force-with religion or

33 C.Pierorazio, Chicago, Ill. to Italian Ambassador, Washington, D.C., ASMAE, Ambasciata di Washington, busta 107, fascicolo 14, "Mobilitazione di italiani negli S.U. per la campagna d'Africa,1896."

34 Italian Consul, Denver, CO., to Italian Ambassador, Washington, D.C., February 14,1896, ASMAE, Ambasciata di Washington, busta 107, fascicolo 14, "Mobilitazione di italiani negli S.U. per la campagna d'Africa, 1896.“

35 Archangelo Pagani, Director of Agency for the Employment of Both Sexes in New York City, to Italian Ambassador, Washington, D.C., ASMAE, Ambasciata di Washington, busta 107, fascicolo 14, "Mobilitazione di italiani negli S.U. per la campagna d'Africa,1896."

36 Professor V.A. Scaletta, Montreal, Canada, to Italian Ambassador, Washington, D.C., ASMAE, Ambasciata di Washington, busta 107, fascicolo 14, "Mobilitazione di italiani negli S.U. per la campagna d'Africa, $1896 . “$

37 Even efforts to raise funds for the war effort became competitive ventures as Barsotti's Il Progresso Italo-Americano indicted rival paper L'Araldo Italiano for allowing an Italian committee from Baltimore to fundraise through their newspaper. L'Araldo Italiano responded by accusing Barsotti, owner of Il Progresso Italo-Americano, of embezzling contributions from his constituents. See L'Araldo Italiano, March 11,1896; Il Progresso Italo-Americano, March 19,1896, March 22,1896. 
with the machine gun. Civilizing the inferior races is not a question of sentiment, it is a necessity that the civilized races cannot ignore." $38 \mathrm{In} I l$ Progresso, Leopoldo Franchetti, an Italian politician who had helped expose terrible conditions in Sicily and supported colonization of Eritrea by Italian peasants, warned "to abandon the Italian colonies was impossible. The great benefit would be in creating an Italian race on the other side of the sea-a democratic society made up of proprietary farmers." 39

After Italy's costly defeat at Adowa in 1896, Italian Americans feared that losing to an African army would not only damage Italian prestige internationally, but exacerbate the existing negative perception of Italians held by many Americans. Therefore, although Adowa did not produce the victorious result desired by the nascent immigrant community, the mainstream press continued to depict Ethiopia with racially informed and bitter characterizations. For instance, various newspapers described victorious Ethiopians as "barbaric cannibals who eat raw meat and do not wear shoes"40 L'Eco d'Italia vividly described the physical attributes of Menelik, the Ethiopian emperor who led the war against Italy, and emphasized his "flat nose with large nostrils, a mouth that is too large along with large teeth that protrude outwards and are very visible as soon as he opens his fat lips. .."41 The Italian language mainstream press also directed some bitterness toward European countries that had assisted African nations with military aid. L'Eco d'Italia lamented that through military assistance to African nations European countries such as Russia and France had violated custom and degraded them. "Russia and France have broken the usual agreement that European nations do not help these kinds of barbarians .... it was understood that European nations went there to bring civilization and progress and that is what Italy is doing." 42 While incredibly humbling and unsuccessful, Italian colonial efforts in Africa during 1896 provided Italian immigrants in the United States an opportunity, albeit briefly, to uplift the Italian race. It is not at all inconceivable that the rhetoric of Italian civilizing missions in Africa ameliorated immigrant self-consciousness, as well as informed a concerted effort to impress American detractors who questioned the racial suitability of Italians. Only fifteen years later, events in North Africa would provide Italians in New York City with another opportunity to bask in the civilized glory of the Italian race and nation.

38 L'Eco d'Italia, March 5,1896.

39 Il Progresso Italo-Americano, June 17,1891.

40 L'Eco d'Italia, March 26,1896; L'Araldo Italiano, March 20,1896.

41 L'Eco d'Italia, April 9,1896.

42 Ibid., April 30,1896. 
After the prospect of colonizing Ethiopia ended abruptly with the defeat of the Italians at Adowa in 1896, an opportunity to avenge this disaster emerged when Italy invaded Tripoli at the end of 1911. As it did in the late nineteenth century, the recently unified Italian Liberal State felt the need to assert itself on the stage of geo-political imperialism. Although part of the Triple Alliance with Austria-Hungary and Germany, the Italian leaders were aware of their nation's relative lack of power and wealth compared to its neighbors. Therefore, late to the table of territorial acquisitions, Prime Minister Giovanni Giolitti resuscitated the Italian campaign for Africa by targeting one of the only remaining areas of Africa to which Italy might possibly lay claim. Although Libya was a desert and not very fertile, one of the primary motivations of the colonialists was the hope that this new colony would provide an area of settlement for the vast number of poverty stricken southern Italians. Italian nationalists hoped that once Libya was an Italian possession, the tide of southern Italian migration would be re-routed closer to home rather than continuing their journey to New York or Buenos Aires. In 1905 Italy had begun a policy of peaceful economic penetration into Libya and slowly created an uncomfortable situation for the Ottoman Turks who ruled the territory. Creating a situation where Italian business interests would seem to need protection, it was the apparent assassination of two Italian officials working in Tripoli in the fall of 1911 that set off a military conflict. Despite the fact that the war remained at a stalemate for months, Italy achieved its aim by default. Benefiting from the Ottoman Empire's increasing weakness, in July 1912 the Turks and Italians negotiated a peace settlement. With the signing of the Treaty of Lausanne On October 8, 1912, Italy formally annexed Libya.

Reflecting the growth of the Italian immigrant community, Italian language mainstream newspapers, specifically dailies such as $I l$ Progresso Italo-Americano, Bolletino della Sera, and L'Araldo Italiano, had matured significantly from their infancy in the 1890s. By 1911 the mainstream press in New York City had combined circulations of over 200,000 copies and enjoyed a much wider readership among Italian immigrants in New York City, as well as outside New York. In addition, proprietors such as Carlo Barsotti at Il Progresso and Frank Frugone at Bolletino had established themselves as community leaders within the Italian colony of New York City. The Italian War over Libya became vehicle for prominenti to offer a version of Italian identity wiped clean of negative stereotypes and racial unfitness. In line with patriotic Italian journals such as Tribuna Illustrata, Barsotti and Frugone, along with the paper's editors, interpreted the Libyan conflict as a means to attain respect, not only internationally, but in a more immediate sense, domestically and locally. 
On September 28, 1911, Bolettino della Sera ran three row headline that shouted "40,000 Italian soldiers headed to Turkey-Italian ultimatum to Turkey blows today." Only two days later the headline read "Tripoli Ours." 43 Bolletino's coverage was not unlike other Italian language mainstream dailies during the conflict that draped their front pages with news about the War, Italian soldiers, and international reaction. This coverage lasted for several months and created an opportunity for Italian language newspapers to build upon the virtues of Italians, the narrative of Italian civilization, and more broadly, the continued construction of an Italian racial identity. The mainstream press was keenly aware of past military failures in North Africa, particularly, the defeat at Adowa in 1896. Frequent allusions to Adowa rationalized the defeats as a function of weak national will, while others referenced how these perceptions remained misguided. Either way, Italy's defeat only fifteen years earlier to Ethiopian forces remained fresh. Although the failed colonial venture in Ethiopia in the 1890s rallied a nascent nationalism among immigrant Italians, the bitter defeat to Menelik's forces certainly stung those Italians in the United States who hoped to gain a measure of respect from imperialist ventures abroad. Military action in Libya in 1911 and 1912 served as a chance for redemption within an emerging nationalist narrative aimed at a disjointed immigrant community, as well as a skeptical American public.

Unsurprisingly, Italy's motives in initiating military actions in Libya were portrayed as noble and unselfish. Some rationales went as far as implying that Italy was a reluctant aggressor, only becoming involved out of patriarchal obligation to reconstitute a fatherless family. ${ }^{44}$ Il Progresso declared "Italy's glorious tricolor flag" would "open the eyes of faraway people in a new era of redemption. It's not the cannon that pushes Italy in Tripoli, but the voice of conscience that brings us to the land of Mohammed to bring a new civility, providence will guide this patriotic action and vile are the people that try to stop the glorious sons of Italy. .."45 Bolletino della Sera agreed stating that "every honest person who knows the situation has to credit the Italians in that Italy does not ask for glory in victory over Turks, but simply wants to end the brutality and protect justice and its people." 46

Intense coverage of the Libyan conflict littered the pages of Italian mainstream newspapers and offered editors and owners a ready-made opportunity to assert Italian civilization. Although northern Africans had

43 Bolletino della Sera, September 28, 1911, September 30, 1911.

44 L'Araldo Italiano, September 29, 1911. L'Araldo retold the apocryphal conversation between an Arab and an Italian in Tripoli: "it's already known, as one Arab said to an Italian, we are like a family without a father."

45 Il Progresso Italo-Americano, October 15, 1911.

46 Bolletino della Sera, October 6, 1911. 
sometimes been distinguished from central Africans, in this instance the mainstream press facilely depicted Africans in Tripoli as savage and neatly viewed the region as part of Africa tenebrosa. ${ }^{47}$ Along with descriptions of Turks as "barbarous" people who represented a "black spot" on human progress, Italian language mainstream newspapers perceived the conflict as a battle between civilization and savagery, Islam and Christianity, light and darkness. ${ }^{48}$ For example, citing the proximity of Tripoli to the island of Sicily as a prime and obvious factor, in the Italian government's interest in the area, Il Progresso Italo-Americano remarked that the city "remained in the hold of medieval barbarism." 49 Bolletino della Sera added that "there has never been a more favorable occasion to redeem European civilization and put an end to the orgies of Turkey that consist of slaughtering Christians." 50

To Italian language editors and owners, the reaction of the American and many European newspapers to the outbreak of hostilities in Libya served as an occasion to defend Italian honor and define Italian civilization. ${ }^{51}$ In one instance, Il Progresso took great umbrage at American newspapers, and in particular a London newspaper that published a cartoon lampooning the Italian colony, and in particular Sicilians in Libya as a band of criminals. Sensitive to negative depictions of southern Italians as prone to criminality, Il Progresso seamlessly conflated their defense of Italians within the context of African colonization stating "that it was high time for the world to stop printing nonsense about Italians in general and Sicilians in particular." 52 Italian language newspapers interpreted Italy's invasion of Libya as proof to Americans that Italy, and by extension, Italian immigrants belonged within the pantheon of civilized nations and peoples. To that end, Italian language mainstream newspapers closely monitored American press coverage and frequently updated its readers with translations of American newspaper articles supporting Italian colonialism in Africa. In one instance, multiple newspapers swiftly praised the work of New York Evening Journal writer, Arthur Brisbane, for defending Italian actions in Libya. Almost as if to convince themselves, rather than Americans, L'Araldo Italiano insisted that "without a doubt, with this war American sympathy will be with Italy, that is, with intelligence and civilization against barba-

47 Il Progresso Italo-Americano, October 15, 1911; October 8, 1911; Bolletino della Sera, October 7, 1911. L'Araldo Italiano stated that "the European colony of Libya is like a loose flap of the mother country on the black continent." L'Araldo Italiano, October 9, 1911.

48 Il Progresso Italo-Americano, Oct 15, 1911.

49 Ibid., September 29, 1911.

50 Bolletino della Sera, October 7, 1911.

51 See examples in Il Progresso Italo-Americano, October, 2, 1911; October 17, 1911; L'Araldo Italiano, October 1, 1911.

52 Il Progresso Italo-Americano, October 2, 1911 
rism. ...53 American responses that questioned Italy's motives and methods in Libya only served to frustrate and anger Italian language mainstream editors and owners. In an article titled, Civilization and Chivalry of the Italians, the author is confused as to how American journals could possibly defend savagery over civilization. Highlighting differences between western, civilized, and Christian nations from Muslim countries, Il Progresso reminded western newspapers of Turkish massacres in Armenia and added "the difference between Italian civilizations is that we treat all people the same way." 54

Mainstream owners and editors interpreted events in Tripoli within the context of an emerging collective identity as Italians informed by an italianita generated from their experience in the United States. And, as they had done in the past, they took the lead in stoking, and in many respects creating, a collective Italian racial consciousness. L'Araldo Italiano described the jubilant displays of Italians whose excitement and pride over the Italian conquest sent the paper's editions, along with its evening journal, Il Telegrafo, flying off the newsstand. Reflective of the importance and reach of the immigrant press within Italian colonies, $L$ 'Araldo stated "whoever has a newspaper - and everyone has one in the Italian community—reads aloud the latest news to everyone." 55 By March readers could see full-page advertisements peddling the latest illustrated editions of the "true and complete history of the Italian and Turkish War."56 Akin to Columbus Day celebrations and exhortations to have Italian language taught in New York City schools, proprietors such as Barsotti organized subscription drives to collect money in support of Italian soldiers and their families. One such drive in Il Progresso in December of 1911 pointed to the "colonies meritorious charity to the race" and listed the names of donors who were instrumental in "renewing the ancient glory of Rome" in their support of Tripoli's conquest. ${ }^{57}$ $L$ 'Araldo Italiano also ran a public subscription drive urging Italian immigrants to support the cause with the headline: "For Heart, Patriotism, and National Dignity." 58 Quick to point out the fervency of the New York City Italian colonies in support of the Tripoli invasion, newspapers

53 See Il Progresso Italo-Americano, October 2, 1911; October 7, 1911; October 11, 1911; Both L'Araldo Italiano and Bolletino della Sera prominently noted, as if to suggest the imprimatur of legitimacy, that the New York Evening Journal was part of William Randolph Hearst's publishing empire. See Bolletino della Sera, October 6, 1911; L'Araldo Italiano, October 6, 1911; Quote is from L'Araldo Italiano, October 1, 1911.

54 Il Progresso Italo-Americano, October 17, 1911.

55 L'Araldo Italiano, October 1, 1911.

56 Il Telegrafo, March 14, 1912.

57 Il Progresso Italo-Americano, December 17, 1911.

58 L'Araldo Italiano, November 22, 1911. 
reported that the "hearts of immigrants beat in unison with that of the mother Italy." 59

Although loathe to admit it, prominenti sought to capitalize on this moment of conquest, especially during this crucial period, by tracing Italy's invasion of Tripoli as part of a legacy of imperialist conquest directly stretching back to ancient Rome. With headlines such as "Viva Italia!" articles laden with jingoistic language celebrated how military conquest would serve as redemption for Italians, and by extension Italian immigrants. ${ }^{60}$ L'Araldo Italiano positioned this battle neatly within the context of Roman history and proudly asserted that Italian soldiers were" fighting with heroism in their blood against a horde of marauding barbarians." Il Progresso urged the Italian military to "re-conquer what used to belong to Rome." 61 Some contended that now Italy's position was stronger than in the past. According to Bolletino della Sera, "for centuries. . .the Italian people and the great people of Rome had soldiers trying to civilize Africa. So the civilized world should applaud Italy of today, stronger, better and more noble than ancient Rome for proposing to civilize Africa and transform its desert into fertile land."62 Italian mainstream newspapers' differentiation between Italian civilization and African savagery, neatly incorporated Calabrians, Neopolitans, Sicilians, and all other provincial Italian immigrants into a collective identity that could stretch its lineage back to the Roman empire: "the people from the Italian Alps, crowned with glory to the great and "noble Sicily from the Adriatic to the Tyrrhenian sea littered with superb destinies where Galileo kept his head bowed on the sacred work has responded with a great patriotic fervor of the Italian Red Cross appeal in favor of families dead and wounded in the fighting in Roman Tripoli." 63

"Viva l'Italia!" declared L'Araldo Italiano as they reveled in the glory of Italy's attempt to bring "light" to the evil Ottoman Empire. However, addressing this historically fragmented community of New York Italians, L'Araldo, cautioned that in this anxious moment, it was imperative to transcend differences and "only be Italian." The paper fervently hoped that success in Tripoli would erase the "gray vision. . .of Adua in front of our eyes and in our soul." 64 Consistent with prominenti efforts to smooth over historical divisions among Italian immigrants, coverage of colonial ventures into Africa served multiple purposes. Por-

59 Il Progresso Italo-Americano, September 30, 1911.

60 L'Araldo Italiano, September 30, 1911; Also see L'Araldo Italiano, September 29, 1911; Il Telegrafo, October 18, 1911; October 23, 1911.

61 L'Araldo Italiano, November 22, 1911; Il Progresso Italo-Americano, September 30, 1911.

62 Bolletino della Sera, October 6, 1911.

63 L'Araldo Italiano, November 22, 1911.

64 Ibid., September 30, 1911. 
traying Italy's motives as noble and benevolent, Italian language mainstream newspapers defended military aggression with paternalistic rationales resonant of the white man's burden. Graphically differentiating Italian and Christian civilization from the Turk, African, and Muslim barbarians, prominenti, such as Barsotti, utilized aggression against an African other to explicitly contrast civilized Italians from savage Africans. Italian immigrants were thus bombarded with patriotic and nationalistic rhetoric and images attempting to replace immigrant insecurities with Italian racial pride. Prominenti interpreted military ventures within the most glorious example they could conjure: the Roman Empire. In the process, the glory of Rome would serve as an instrumental force in healing the emotional and political wounds still lingering from the humiliation at Adowa. Consistent with subscription drives to honor Italian heroes such as Columbus and Dante, or efforts to have the Italian language taught in New York City schools, proprietors such as Barsotti and Frugone tapped into the glory of Rome as a strategy in identity formation well before Benito Mussolini's rise to power in the 1920s. With an eye toward an American audience, as much as the Italian immigrant community, the prominenti press perceived and transmitted military dominance of an African country, not only as evidence of Italian civilization, but as a venture that was seamlessly rooted in the newly imagined Italian past. Instrumental in these appeals to immigrant patriotism and national pride was the construction of an image of Africa as dark, primitive, and savage. 